активно застосовують у багатьох країнах світу для формування й удосконалення компетентностей зі здоров'язбереження, для розроблення освітніх стандартів щодо здоров'язбереження.

У ході дослідження підтверджено доцільність використання методу оцінки цільовою групою своїх потреб щодо здоров'язбереження. Акцентуємо на тому, що запропонований метод оцінки цільовою групою своїх потреб щодо здоров'язбереження має ретроспективний та прогностичний характер i може використовуватися переважно для аналізу ситуацій з огляду на їх позитивний чи негативний уплив на життя цільової групи та кожного 3 iї членів. У процесі використання методу ОЦГП можуть бути окреслені як загальна проблема, так і окремі проблеми, що іiі складають.

\title{
Література
}

1. Global recommendations on physical activity for health / Глобальные рекомендации ВОЗ по физической активности для здоров'я [Електронний ресурс]. Режим доступу: http://whqlibdoc.who.int/publications/2010/9789244599976_rus.pdf// World Health Organization. - 2010. - 60 c. 2. Основи громадського здоров'я: теорія і практика: [навч.-метод. посібн.] / за заг. ред. О. В. Безпалька. - Ужгород : ВАТ «Патент», 2008. - 322 с. 3. Глобальная стратегия ВОЗ по питанию, физической активности и здоровью: Руководство для стран по мониторингу и оценке осуществления. - Всемирная организация здравоохранения. - Женева, 2009. - 47 с. Режим доступу: http:/whqlibdoc. who.int/publications/2010/9789244599976_rus. pdf. 4. Соціальна робота: Технологічний аспект: [навч. посібн.] / Держ. центр соц. служби для молоді; Ін-т соц. роботи та управління НПУ ім. М.П. Драгоманова; за ред. А. Й. Капської. - К., 2004. -364 с.

УДК 378.147

Наталя Чувасова

\section{ФОРМУВАННЯ КРЕАТИВНОЇ ПОЗИЦЇ̈ МАЙБУТНІХ УЧИТЕЛІВ ХІМЇ̈ ТА БІОЛОГІЇ У ПРОЦЕСІ ФАХОВОЇ ПІДГОТОВКИ}

Чувасова Н. О. Формування креативної позиції майбутніх учителів хімії та біології у процесі фахової підготовки.

У статті на основі зіставлення, порівняння, узагальнення наукової інформації феноменів «творчість», «креативність», «професійна позиція», «креативна позиція» розглядаються різні підходи до визначення цих понять. Виокремлено креативні якості, чинники, умови та етапи формування креативної позиції майбутніх учителів хімії та біології.

Ключові слова: креативність, творчість, творчий процес, професійна позиція, креативна позиція.

Чувасова Н. А. Формирование креативной позиции будущих учителей химии и биологии в процессе профессиональной подготовки.

В статье на основе сопоставления, сравнения, обощения научной информации феноменов «творчество», «креативность», «профессиональная позиция», «креативная позиция» рассматриваються различные подходы к определению этих понятий.

Ключевые слова: креативность, творчество, творческий процесс, профессиональная позиция, креативная позиция. 
Chuvasova N. A. Formation of the creative position of the future teachers of chemistry and biology during training.

On the basis of comparison, comparison, synthesis of scientific information phenomenon of «creative», «creativity», "professional position», «creative attitude» discusses various approaches to the definition of these concepts. Author determined creative quality factors, conditions and stages of the creative position of the future teachers of chemistry and biology.

Key words: creative, creativity, professional attitude, creative position.

Нині створюються передумови для перегляду теоретичних основ і технологій підготовки фахівців до різних сфер професійної діяльності. Подолання репродуктивного стилю підготовки вчителів хімії та біологіїі перехід до нової освітньої парадигми передбачає і нові вимоги до підготовки педагогічних кадрів, які забезпечують пізнавальну активність, творчість, креативність дій та мислення особистості і є стратегічними напрямами в модернізації вищої педагогічної освіти.

Навчальним процесом у вищій педагогічній школі має формуватися самостійна, творчо мисляча особистість педагога, який буде здатний проводити навчальний процес на високому рівні інтелектуального та креативного розвитку учнів, володіти дослідницькими методами навчальної роботи.

Актуальність проблеми формування креативної позиції посилюється тим, що креативна позиція вчителя $є$ основою його професіоналізму, творчого потенціалу, продуктивної професійної діяльності, стає стимулом розвитку особистості педагога, його самоосвіти, самовиховання, професійного самовдосконалення.

Meта cmammi - проаналізувати підходи науковців щодо формування креативної позиції майбутніх учителів хімії та біології у процесі фахової підготовки, скорегувати понятійну базу.

Досліджено, що «креативність» науковці розуміють по-різному: як інтелектуальну активність (Д. Богоявленська), здібність (загальну - О. Морозов, творчу інтелектуальну - М. Холодна, духовну - В. Шадріков), процес (П. Торренс, Г. Уоллес), особистісні якості (Дж. Катена), життєвий стиль чи особистісний розвиток (А. Маслоу, К. Роджерс), когнітивний процес (Дж. Гілфорд, П. Торренс), продукт (Г. Гарднер, Дж. Катена, Д. Перкінс). Деякі дослідники вбачають іiі у здатності особистості досягнути креативного результату у процесі напруженої діяльності у сприятливому середовищі (Р. Муні, М. Роудз, Г. Еквалл, С. Ісаксен). Серед праць із психології творчості можна знайти розробки різноманітних іiі аспектів. Це, зокрема, спроби пояснити сутність творчості та творчого процесу (В. Моляко, М. Ніколаєнко, Я. Пономарьов, В. Роменець та ін.), визначити специфіку творчості в тій чи тій галузі знань (Т. Кудрявцев, М. Ярошевський та ін.), пошук шляхів оптимізації та активізації творчого мислення (Г. Альтшуллер, Г. Буш, В. Моляко, І. Семенов та ін).

У трактуванні сутності професійної позиції особистості педагога теж немає єдності. Одні їі вбачають в «орієнтації» (С. Вершловський), інші - «в мотиваційній сфері» (Т. Шібутані), треті трактують іiі як «духовний центр» (Б. Ананьев), «систему установок» (школа Д. Узнадзе), «спрямованість» (Л. Божович); «відношення» (В. М'ясищев), «як внутрішній компонент структури особистості» (Б. Ананьєв, Л. Божович, Л. Кондрашова, Л. Крамущенко, І. Луценко, А. Маркова, В. Сластьонін, К. Ушинський) та інші.

Ми погоджуємось 3 академіком І. Зязюном, який визначає творчість як процес створення суб'єктивно нового, котре грунтується на здібності висувати оригінальні 
ідеї, використовувати нестандартні способи діяльності [6, с. 123].

Креативність - здатність генерувати нові, оригінальні ідеї, знаходити нетрадиційні способи розв'язання проблемних завдань. Отже, креативність $\epsilon$ складником творчості, вияви й різновиди якої визначаються тріадним підходом: стимулювально-продуктивним, евристичним, креативним.

Креативність як здібність до творчості розглядаємо, погоджуючись із В. Шадріковим, як синтез інтелектуальних здібностей і духовного стану (розширення свідомості, активне включення у процес пізнання істини підсвідомості, гармонізація особистості, внутрішня рівновага, образне мислення, висока моральність та емоційність, висока продуктивність уяви, духовні цінності - любов до студентів і віра в них) [8, с. 312].

Грунтуючись на дослідженнях психологів Дж. Гілфорда, Е. Торранса, А. Маслоу, В. Рибалки, В. Роменця та ін., трактуємо креативність як динамічну інтегративну

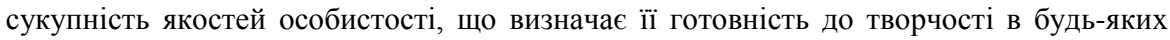
галузях людської діяльності; як творчі здібності людини, які можуть виявлятися в мисленні, почуттях і діях; як здатність породжувати різноманітні оригінальні ідеї. Креативність $є$ необхідною умовою самореалізації особистості.

Методологічне значення для нашого дослідження має твердження Х. Бергсона, Ф. Голмена, Е. Фромма, С. Франка та ін., що креативність притаманна більшості психічно здорових людей, але ступінь іiі розвиненості в кожного індивіда різний. Її основу становлять психофізіологічні задатки,розвиток яких детерміновано численними факторами:

- особистісними (внутрішніми) - психологічними, фізіологічними та іншими особливостями суб'єкта;

- соціальними (зовнішніми), дія яких визначається зовнішніми обставинами й не залежить від суб'єкта діяльності.

У дослідженні креативна позиція майбутніх учителів хімії та біології визначена як професійно-особистісна характеристика, що відображає креативні ціннісні ставлення студента до професійної діяльності та їі результатів; учасників освітнього процесу (викладачів,студентів,батьків) й забезпечує умови для реалізації професійнорольових функцій під час навчання.

Психолого-педагогічні дослідження Г. Костюка, I. Кона, Т. Артем'євої, В. Лісовського, І. Головатого, А. Крупнова, В. Шевчука та інших засвідчують, що в юнацькому віці, коливизначається життєва мета, важливими чинниками розвитку молоді постають професійна освіта та самоосвіта.

Креативною позицією майбутніх учителів хімії та біології, яка охоплює всі сфери діяльності студента, передбачається умотивованість до здійснення креативної педагогічної діяльності; сукупність психолого-педагогічних знань, що забезпечують теоретичну та креативну готовність до розв'язання педагогічних задач 3 позиції гуманізму й ненасилля; умінь, якість засвоєння й узагальнення яких необхідна для успішної практичної креативної діяльності педагога; засвоєння механізмів рефлексії.

Креативна позиція виявляється в уміннях сприймати й нестандартно розв'язувати проблеми, використовуючи найбільш оптимальні засоби, успішно взаємодіяти 3 оточенням, особливо за нестандартних ситуацій, втілюваних у спроможності створювати оригінальні продукти, які мають особистісну й соціальну значущість; у здатності до створення нового.

Формування креативної позиції особистості - це глибинний процес внутрішніх кількісних і якісних змін іiі психологічних, інтелектуальних і духовних сил, що 
відбувається на основі активності індивіда й забезпечується його творчою самореалізацією.

На основі психолого-педагогічних досліджень В. Андреєва, Н. Вишнякової, В. Кан-Калика, М. Никандрова, В. Рибалки та інших можна вибудувати модель креативних якостей особистості, професійно сутнісних для творчої методичної діяльності майбутнього вчителя хімії та біології, вона передбачає:

1) мотиваційно-креативні властивості: мотиви, інтереси, потреба в самореалізації; творча позиція;

2) емоційно-креативні властивості: емпатія; багатство емоційного досвіду; експресивна та імпресивна емоційність;

3) інтелектуально-креативні властивості і здібності: інтуїція; здатність до перетворень; уява й фантазія; дивергентне мислення;прогнозування;

4) естетично-креативні властивості та здібності: прагнення до краси; естетична емпатія; почуття форми, стилю; почуття гумору;

5) комунікативно-креативні властивості: співробітництво у творчій діяльності; здатність мотивувати творчість інших; акумулювати творчий досвід;

6) екзистенціально-креативні властивості: позитивна «Я-концепція», нонконформізм; індивідуальний стиль діяльності.

Опрацювання теоретичних джерел (Н. Вишнякова, М. Гнатко, П. Просецький та ін.) дало змогу з'ясувати, що креативна позиція педагога формується на основі наслідування досвіду, ідеї, окремого прийому, форми, методу 3 поступовим зменшенням частки наслідувального й зростанням частки творчого компонента в методичній діяльності. Цю динаміку можна відтворитиу схемі: наслідування копіювання - творче наслідування - наслідувальна творчість - самостійна творчість.

За твердженням М.Гнатка, у процесі такого послідовного перетворення відбуваються зміни в особистісній сфері індивіда, а саме перехід його потенційної (додіяльнісної) креативності в актуальну (набуту в процесі методичної діяльності).3'ясовано, що в навчальному процесі фахової підготовки рух від потенційної до актуальної креативності передбачає такі дії:

- створення ситуації, що вимагає від студентів знаходження невідповідності між наявним і необхідним рівнем знань і вмінь задля визначення перспектив саморозвитку;

- наслідування креативного зразка, яким може стати передовий педагогічний досвід, особистість шкільного вчителя, викладача ВНЗ, видатної людини, науковцятощо;

- організацію навчання 3 урахуванням розширення креативних потенційних можливостей студентів [3, с. 23].

Розвиток креативної позиції майбутніх учителів хімії та біології $є$ важливим складником їхньої професійно-методичної підготовки; цебагатовимірний процес якісних змін психологічної сфери особистості, що відбувається поетапно і в логічній послідовності за певних психолого-педагогічних умов із використанням методів, прийомів, видів, форм і засобів навчання, котрі найбільш ефективно впливають на підвищення творчого потенціалу студентів у процесі фахової підготовки.

У формуваннікреативної позиції студентів можна виокремити триетапи:

- діагностично-інформаційний, що передбачає підготовку до формування професійно-креативних якостей майбутніх освітян, надання їм знань про особливості методичної діяльності вчителя хімії та біології, ii нормативний і творчий компоненти, діагностування рівня потенційної креативності особистості;

- репродуктивно-творчий етап, метою якого є засвоєння студентами знань i способів діяльності, навчання їх комбінуванню, трансформації і відбору відповідно 
дореальних умов; моделювання навчально-виховного процесу з внесенням елементів новизни;

- творчо-репродуктивний етап, на якому студенти набувають уміння творчо моделювати процес викладання хімії та біологіїв школі.

Формування креативної позиції майбутніх учителів хімії та біологіїв умовах фахової підготовки набуває ефективності, якщо:

- відбувається в умовах неперервності і цілісності реалізації особистіснодіяльнісного підходу;

- забезпечує гармонізацію змістової, процесуальної, інтелектуальної та емоційної сторін змісту підготовки;

- спрямовує навчально-виховний процес на формування мотиваційного, операційного та особистісного компонентів креативної позиції студентів вищих навчальних закладів, що узгоджуються 3 критеріями та впливають на рівень іiі сформованості;

- досягає результативності за умов забезпечення стійкої мотивації студентів до формування власної креативної позиції, культивування еталона креативної, гармонійно розвиненої особистості;

- підвищує інтерес майбутніх учителів хімії та біологіїдо креативної діяльності за рахунок добору традиційних та нетрадиційних засобів навчання, методів, які впливають на конвергентне і дивергентне мислення, організаціюта стимулювання креативної діяльності; контроль за ефективністю креативних дій і форм;

- освітнє середовище забезпечує психологічну безпеку та психологічну свободу майбутнім учителямхімії та біологіїв умовах фахової підготовки.

Особистість здатна розглядати власну креативну позицію як предмет практичного перетворення себе. Поряд 3 цим вона може досягти вищої форми креативності, що полягає в її творчій самореалізації.

Методологічна основа формування креативної позиції об'єднує ідею про формувальну роль діяльності; особистісно зорієнтований, змістово-процесуальний, діалогічний, задачний та імітаційно-ігровий підходи до структурування природничих знань та технології оволодіння студентами професійно-педагогічними діями; ідею цільової настанови навчальної діяльності - формування креативної позиції майбутніх учителів хімії та біології.

Креативна позиція як мета професійної підготовки прогнозуєформування творчої особистості в усіх видах діяльності, діалогічну взаємодію та спілкування, перебудову креативного стилю діяльності студентів 3 оволодіння знаннями 3 природничих дисциплін.

Вихідним положенням концепції $\epsilon$ теорія єдності та взаємозумовленості змістовного та діяльнісного аспектів у структурі підготовки майбутніх учителів хімії та біології до креативної педагогічної праці, гармонізації інтелектуальної та емоційної сторін у творчому педагогічному процесі, яке досягається через:

- забезпечення психологічної безпеки та психологічної свободи;

- розвиток уміння розв'язувати творчі завдання;

- розвиток інтуїції як сукупності знань, інстинктів, емоцій, моралі та ціннісних суджень;

- розширення світогляду, використання в навчальному процесі методів, що сприяють розвитку здібностей до мислення і сприймання;

- перенесення акцентів 3 інформативного навчання на діалогічне, із змісту навчання на його засоби, що сприяє розвитку загальних інтелектуальних здібностей, 
які лежать в основі різних видів творчої діяльності.

Визначаючи організаційні форми й методи проектованої моделі навчальнометодичної системи, ми керувалися твердженням Р. Грановської [4, с. 154], що розвитку креативних якостей особистості більше сприяють інтенсивні форми й методи навчання. Вони, на відміну від репродуктивно-інформаційних, спрямовані не лише на розвиток логічних операцій мислення, а й на розкріпачення правопівкульних процесів психічної діяльності - стимулювання дивергентного мислення, інтуїції, уяви, фантазії, натхнення, антиципації, емпатії тощо.

Інтенсивними методами, формами i прийомами навчання вважаємо такі, використання яких надає навчальній діяльності студентів творчого характеру, сприяє інтенсивному формуванню їхніх пізнавальних інтересів i розвитку професійнокреативних якостей. Це проблемний виклад матеріалу, проблемна лекція, евристична й проблемно-пошукова бесіди, проблемно-пошукові й дослідницькі завдання, різноманітні дискусії, дидактичні ігри, семінари, конкурси, тренінги, кейс-метод, розроблення проектів, збір портфоліо тощо.

Отже, процес формування креативної позиції майбутніх учителів хімії та біології $\epsilon$ складним, динамічним, педагогічно керованим. Від ступеня сформованості цього складного особистісного утворення залежить рівень професіоналізму сучасного фахівця.

\section{Література}

1. Актуальні проблеми психології творчості:[зб. наук. праць] за ред. В. О. Моляко. - Житомир : Вид. ЖДУ ім. І. Франка, 2007. - Т. 12. - Вип. 3. - 318 с. 2. Варламова Е. П. Психология творческой уникальности / Варламова Е. П., Степанов С. Ю. - М. : Институт психологии РАН, 2002. - 256 с. 3. Гнатко Н. М. Проблема креативности и явления подражания /Николай Митрофанович Гнатко.М. : Институт психологии РАН,1994. - 43 с. 4. Грановская Р. М. Конфликт и творчество в зеркале психологи / Р. М. Грановская. - М. : Генезис, 2002. - 573 с. 5. Исследование проблем психологии творчества / Я. О. Пономарев. - М. : Наука, $\begin{array}{llllll}1983 . & 336 \text { c. } & \text { 6. Педагогічна майстерність: [підручник] } & \text { I. А. Зязюн, }\end{array}$ Л. В. Крамущенко, І. Ф. Кривонос та ін.; за ред. І. А. Зязюна. - К. : Вища шк., 1997. 349 с. 7. Психологічне дослідження творчого потенціалу особистості : [монографія] / авт. кол.; наук. керівник В. О. Моляко. - К. : Педагогічна думка, 2008. - 208 с. 8. Шадриков В. Д. Психология деятельности человека/ Владимир Дмитриевич Шадриков. - М. : Изд-во «Институт психологии РАН», 2013. - 464 с. 